\title{
Perspectives
}

\section{To Challenge the Unchallenged: Potential of Non-"Standard" Englishes for Japanese EFL Learners}

\author{
Kazufumi Miyagi \\ Masatoshi Sato \\ Alison Crump \\ McGill University
}

This paper calls for a broadening of the discussion of English language teaching (ELT) practices in Japan. We review issues associated with the global spread of English and link this discussion to the present "standard" English model of ELT in Japan. We propose three major benefits that would follow from an inclusion of non-"standard" (i.e., non-American/British) Englishes in Japanese EFL classrooms. First, familiarity with different varieties could increase learners' confidence when interacting with other nonnative speakers (NNSs). Second, we review literature that shows that NNS-NNS interactions actually help learners improve their language skills. Finally, recognition of non-"standard" varieties of English would help Japanese learners challenge monolithic western-centric worldviews that marginalize regional, cultural, and linguistic norms and values. We connect this theory to practice by suggesting some possible changes to ELT in Japan.

本稿では、英語・米語に代表されるいわゆる標準英語の社会的文化的な影響について指摘 し、日本英語教育において標準英語に対抗すべく多様な「非標準】英語の教育的可能性を探る ものである。著者それぞれの研究を踏まえ、英米語に加え「非標準」英語を日本の英語教育現場 で積極的に活用することで期待できる利点を三つ提唱する。第一に「非標準」英語に親しみを

JALT Journal, Vol. 31, No. 2, November 2009 
持つことにより、ハンネイティブ話者同士の対話に自信が持てるようになる。第二にハンネイティ ブ話者同士による対話活動は実際に第二言語習得に効果的である。第三に、「非標準」英語に 触れることが、西洋的視点に偏りがちな日本人の世界観を省みる機会となり、多様な文化、言語 に対する認識の向上が期待できる。以上の点を考察した上で、最後に英語教育現場における「 非」標準英語の具体的な導入法ついて提案する。

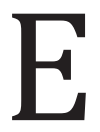

nglish continues to be widely used as the language of international communication and there have been growing debates regarding what model of English is most appropriate for learners. This paper draws from and integrates three studies that were conducted independently, but that intersect on the same key issue: supporting and expanding a paradigm shift away from using "standard" (i.e., American/British) English as the sole model in Japanese English language teaching (ELT). We begin with a cursory overview of some of the critical issues relating to ELT, a field whose theories and practices are traditionally based on standard English norms. Second, we consider Japanese perceptions of and attitudes toward different varieties of English. Finally, we propose benefits of including non-"standard" Englishes in English as a foreign language (EFL) classes in Japan. We also identify several practical ways to challenge the widely accepted status quo, in which standard English goes unchallenged.

\section{English in the Global Context}

With the recognition of the diversity of English in the world, there are repeated calls for a shift from a monocultural view of English standards to multicultural, fluid perspectives that respect local varieties (Bhatt, 2001; Canagarajah, 2006; Kachru, 1992). Despite the varying conceptualizations of English as an international language and repeated arguments for a reconsideration of goals and approaches of ELT (e.g., Honna \& Takeshita, 1998; Jenkins, 1998; Matsuda, 2003; McKay, 2002; Rubdy \& Saraceni, 2006), standard English maintains a stranglehold in many EFL contexts, and Japan is no exception.

On the one hand, there is a powerful push toward teaching standard English because it is the language associated with power in economy and foreign policies. Accordingly, the "privilege" associated with this variety of English persists rather non-polemically in many contexts. The high demand for this variety of English is endorsed by massive resources from those who are considered to be the "owners" of the language, which results in significant economic disparities between those on the supply side and those on 
the demand side of the ELT industry (Phillipson, 1992). Nevertheless, it is argued that a teaching model based solely on standard English excludes most learners of English from the chance to benefit from the socioeconomic advantages that are considered to be available to owners of those varieties (Lippi-Green, 1997; Phillipson, 1992). This hegemony of English has well documented and significant ramifications for regional languages and cultures as well (e.g., Bruthiaux, 2002; Kubota, 1998; Niño-Murcia, 2003; Pennycook, 1998; Phillipson, 1992; Tsuda, 1990; 1997). For instance, in Peru, which was once a Spanish colony, English is now overriding the enduring colonial linguistic hierarchy, where Spanish dominated Quechua, an indigenous language. This shift to English has created a challenge to the future of Quechua (Niño-Murcia, 2003).

On the other hand, there is a growing acceptance that English is a language to which many claim ownership (Kachru, 1992; Widdowson, 1994). Some varieties of English, especially in post-colonial contexts, have begun to rely on endonormative standards (Canagarajah, 1999; Kramsch \& Sullivan, 1996), meaning that ELT models are based on their local variety/ies of English. In such contexts, the language is no longer a symbol of monolithic Western culture, but rather, it "represents a repertoire of cultures" (Kachru, 1992, p. 362). Unfortunately, this perspective has not permeated approaches to ELT in many EFL contexts, including Japan. What we argue for is not a full-fledged endonormative model for ELT in Japan, but an approach that takes into consideration the country's socio-political relationship with the English language.

\section{English in the Japanese Context}

The notion in Japan that standard English is the model to study has its roots in Japan's socio-political history with the West. Around the end of the 19 th century, the rapidly modernizing Japanese government made a deliberate decision "to catch up with the advanced civilization of the Western world" (Koike \& Tanaka, 1995, p. 16). During the involvement of the United States in Japan's revitalization after World War II, English became a "symbol of 'happy and rich' American people" (Tanaka \& Tanaka, 1995, p. 123). Although Japan has never been physically colonized and forced to use English, the postwar willingness to accept Anglo-centric language and culture without question prevails (Suzuki, 1999). Tsuda (1990) warns that Japanese EFL learners are being "mentally" colonized by this process. Kubota (1998) and Tsuda (1997) further argue that the domination of standard English encourages learners to take up a worldview that is Anglo-centric. Such a devotion to the language 
can blind people to the multiplicity of Englishes in the world, resulting in learners' indifference and ignorance toward speakers of other varieties of English.

Japan's test-driven culture further reinforces the position of standard English, as it has become one of the key subjects that Japanese students have to study to achieve academic milestones such as passing high school and university entrance examinations (see Bardovi-Harlig \& Dörnyei, 1998). Standard English is also regarded as the language of social success, and many Japanese people connect a good command of English with attaining an affluent life style. Matsuura, Fujieda, and Mahoney (2004) report that both college students and their instructors agreed that English is a prestige language in terms of job opportunity. In fact, a growing number of companies have begun to adopt scores on a standardized English proficiency test, namely the Test of English for International Communication (TOEIC), as one means to screen applicants and decide on employees' promotions (TOEIC, 2007). Although it is not unusual to observe that someone with a high score on a proficiency test cannot perform orally as well as his/her score implies (Torikai, 2002), scores on these tests can undeniably serve a gate-keeping function. It is no surprise, therefore, that the question of how to acquire a good command of English (or how to get good marks on tests) is a common topic of conversation throughout all domains of life in Japan.

Although some have pointed out that Japanese EFL learners tend to put more emphasis on American usage (McArthur, 2003), many Japanese English learners do not actually make a qualitative distinction between American English and British English (Matsuda, 2003). This lack of consideration of other varieties in Japanese ELT is supported by the linguistic environment outside of classrooms, where the mass media largely reflect Anglo-centric linguistic and cultural norms (Tanaka, 1995).

\section{Influence of ALTs}

A significant factor in securing the role of the standard English model in Japan has been the focus on increasing students' communicative language skills. This has been increasingly emphasized in the Course of Study for Foreign Languages (Ministry of Education, Culture, Sports, Science and Technology [MEXT], 2003) since the 1980s. Having a good command of communicative language skills is seen as a key factor in preparing students to interact with the international community, which has obvious economic and political benefits for Japan. This emphasis on communicative skills re- 
flects a political movement called kokusaika (internationalization) that was initiated in the mid-1980s an effort to quell trade tensions with the west. Since kokusaika is a movement that is focused on Japan's relationship with the west in particular, it is no surprise that native speakers of English from western countries have been recruited in increasing numbers to work as assistant language teachers (ALTs) in EFL classrooms. ALTs have now become a fundamental part of English education in Japan, as they are seen to increase the potential for a more communication-oriented learning environment. In general, ALTs are expected to demonstrate standard English usage, to increase students' opportunities for communication, and to function as a point of reference for cultural content related to their countries of origin.

The internationalization movement that was such an integral part of Japanese education reform that began in the 1980s, promotes a narrow view of the international community, however. Because it defines Japan's position in the international community primarily through its relation with western, English-speaking countries (Kubota, 1998), this has significant implications for Japanese ideologies of English. The presence of ALTs has inevitably led Japanese people to accept English spoken in these countries as the absolute varieties, which sustains the hegemony of standard English in Japan.

The majority of ALTs come to Japan through the Japan Exchange and Teaching (JET) Programme, which assigns ALTs to public schools all over the country. Since its inception in 1987, the JET Programme has hosted a total of 59,911 foreign nationals as ALTs of English (Council of Local Authorities for International Relations [CLAIR], 2002; MEXT, 2002). By hiring participants from Western countries associated with standard English varieties, the JET Programme plays a key role in the maintenance of the stranglehold of standard English ideologies in Japan. An overwhelming 99.2\% $(59,434)$ of the English ALTs have come from countries that Japan associates with providers of standard English (i.e., USA, England, Canada, Australia, and New Zealand). Kachru (1992) defines this group, which is associated with the traditional bases of English, as the Inner Circle. While the JET Programme has recently been accepting ALTs from non-Inner Circle countries, the numbers are small and do not sway the stranglehold of Inner Circle ALTs. For example, out of the 5,057 ALTs in 2006, 78 were South African, 39 were Jamaican, 32 were Singaporean, 22 were Indian, and 16 were from Trinidad and Tobago (CLAIR, 2007).

These numbers clearly show the significant influence that the JET Programme has on the marginalization of nonstandard varieties of English. Considering that ALTs' roles involve modelling English usage in their EFL 
classes, Japanese learners are provided with little or no contact with other varieties. Furthermore, Crump (2007) found that ALTs, who are mostly untrained as teachers, promote monolithic ideas about the role of English in the world by their own lack of awareness of nonstandard varieties of English. Thus, Japanese students are not provided with oral/aural input that reflects the actual diversity of English in the world, nor are they encouraged to challenge or expand their views with respect to this diversity.

\section{Perspectives of Japanese Teachers}

The native and nonnative speaker constructs are by no means neutral and have been highly contested in the field of World Englishes (Davies, 1991; Phillipson, 1992); at the same time, there has not been a shift away from these constructs in fields allied to Applied Linguistics, such as Second Language Acquisition. As this paper draws from three interdisciplinary perspectives, we use these terms to address findings in research done in Applied Linguistics which show possible advantages of interactions between learners.

In tandem with the global spread of English, the number of nonnative speakers of English (NNSs) has far surpassed the number of native speakers of English (NSs) (Crystal, 2003; Graddol, 1997). In other words, NNS-NNS interactions will be more commonplace than the NNS-NS exchanges that are the conventional model in EFL teaching. Despite this shift in users of English in the world, unfortunately, NNSs' accents often receive negative reactions from NS listeners (Cargile, 1997). This type of reaction often comes from within NNSs, however, and there are accounts of learners who admire standard English and question the practicality of their nonnative speaking teachers (Tsuda, 2000). However, Japanese EFL learners have been shown time and again to have persistent inclinations for standard English, but little awareness of other varieties, including their own (Honna \& Takeshita, 1998; Yoshikawa, 2005). Not only that, but they also show little interest in gaining an awareness of other varieties (Matsuda, 2003). Similarly, Miyagi (2006) found that Japanese EFL teachers at lower secondary schools had ambivalent attitudes toward nonnative varieties of English. On the one hand, teachers perceived non-American Englishes as unnecessary aural input and were hesitant to include such varieties in their classrooms. On the other hand, they also felt that English should be learned with NNS-NNS interactions in mind because these are likely to reflect their students' future realities. This ambiguity leads us to argue for the need for a broader approach to ELT in Japan. 


\section{Benefits of a Wider Perspective}

The major consequence in Japan and other contexts of adhering to a standard English model without question is an acceptance of the spread of English as natural, neutral, and beneficial (Pennycook, 1994). Although there are clearly powerful forces in place in Japan that offer continued support to this problematic model (e.g., the JET Programme), there are concrete means to rectifying this situation. In this section, we offer three potential benefits of introducing nonstandard Englishes in ELT in Japan. This is followed by some practical suggestions for teachers.

First, increased familiarity with different varieties would help Japanese learners participate in interactions with the many speakers of nonstandard Englishes who partake in international communication every day. Enhancing familiarity with different Englishes does not stand alone, however. Studies have shown that if familiarity with accents is coupled with an increased understanding and acceptance of diverse cultural norms, learners display more confidence in their ability to understand the messages delivered in a particular variety (Cortazzi \& Jin, 1999; Smith, 1992).

Second, NNS-NNS interactions offer learners numerous benefits with respect to improving their language skills. For example, research supports NNS-NNS interactions in driving second or foreign language acquisition forward in terms of both fluency and accuracy (e.g., Foster \& Ohta, 2005; Storch, 2002). More specifically, NNSs collaborate when they encounter communication problems, regardless of whether or not they share their first languages (Kowal \& Swain, 1997; Swain \& Lapkin, 1998). In the process of solving the communication breakdown, learners try to make their language more comprehensible or accurate, which arguably enhances language acquisition. In fact, some studies have shown that learners find more learning opportunities when they interact with each other than when they interact with native speakers who have little or no language teaching training (e.g., Musumeci, 1996; Pica, 2002; Pica, Lincoln-Porter, Paninos, \& Linnell, 1996), such as ALTs. Sato and Lyster (2007) report that Japanese EFL learners feel comfortable interacting with each other, but feel under pressure when interacting with NSs. The reason for this increased tension in NS-NNS interactions is that the learners perceive NSs' standard English as unattainable. The result is that learning opportunities actually decrease because learners are inhibited to speak. Furthermore, NSs who have no ELT training tend not to provide learners with the chance to correct errors on their own; instead, NSs are likely to recast the utterance (Sato, 2007). Once again, the learners are missing out on valuable learning opportunities. Therefore, this high- 
lights the importance of increasing the value of NNS-NNS interactions in EFL classes in Japan.

In addition to increasing learners' confidence in NNS-NNS interactions and increasing learning opportunities, there is one more benefit that we see to the inclusion of nonstandard Englishes in Japanese ELT. Introducing students to different varieties of English effectively challenges the hegemony of English in that it helps learners broaden their worldviews. Unless Japanese people show some resistance to the dominance of standard English in Japan, ELT in Japan will continue "to promote Westernization in various aspects of Japanese life while failing to provide global socio-linguistic perspectives" (Kubota, 1998, p. 302).

Despite these significant benefits, it is not realistic to avoid standard English as an instructional model. A teaching model that several scholars refer to (e.g., Canagarajah, 2006; Matsuda, 2003; Miyagi, 2006) is one that is based on an exonormative standard such as American/British English. However, this model also stresses that this is not the only variety of English. Teaching about other Englishes should be viewed as a way to raise learners' awareness of diverse cultures and languages. With such a model, Japanese students will be able to develop a greater appreciation for their own variety of English, as well as gain the tools needed to engage in communication in the international community with people from various backgrounds. Most importantly, Japanese people will be empowered to make informed decisions and not let one-sided information control their perceptions of speakers of nonstandard varieties of English.

\section{Theory into Practice}

There are several ways to put into practice this idea of introducing other varieties into actual classroom settings. First, more non-Inner Circle ALTs are needed in Japanese EFL classrooms. As stated above, the JET Programme has indeed hired a small number of ALTs from outside the Inner Circle countries; however, there remains much room for improvement. By diversifying the hiring practices of ALTs, EFL classes could become more aurally diverse spaces. Furthermore, learners could begin to develop a familiarity with those non-Inner circle sounds that more appropriately mirror the Englishes used in international communication. Learners would also begin to realize that communicating in English involves more than interaction with an idealized and essentialized standard NS. 
Additionally, audio materials used in EFL classrooms need to be made more phonologically diverse. While textbooks used in EFL classes have become more culturally diverse in content and illustrations, the listening materials attached to those textbooks are conventionally recorded in North American Standard English. As a result, some textbooks create a rather odd situation where two interlocutors (e.g., a Korean boy and his Japanese host mother) are conversing in "perfect" American English. It would be of great value to include other Englishes, such as Australian, Singaporean, or Indian, as well as other non-Western varieties such as Chinese, Japanese, or Korean. Although some textbook developers have attempted to include speakers of various Englishes in their audio materials for college-level English courses (Morrison \& White, 2005), such efforts also need to be seen in the development of the secondary and lower secondary textbooks approved by MEXT.

There are some important considerations that have to be acknowledged when introducing nonstandard Englishes to actual learning settings. First, teachers should be careful not to encourage learners to be judgmental towards unfamiliar accents. Rather, teachers should take advantage of this opportunity to help their students realize that what counts most in using English (or any language, for that matter) is not how one sounds but what message he/she wants to convey. This approach could help increase Japanese students' confidence when speaking their own English.

Next, it is essential that the work done with different Englishes in EFL classes not be used as a means of evaluating students. The idea is not to replace the current standard English model upon which the heavily testdriven culture of ELT in Japan is based, but rather to complement it. The aim is to increase teachers' and learners' awareness of other Englishes and for Japanese people to begin to accept these other Englishes, including their own Japanese-accented English, as legitimate entities in the international context. An integral part of the paradigm shift that we envision, therefore, involves instructors becoming co-learners with their students, rather than taking up conventional roles as knowledge providers.

\section{Conclusion}

In this paper, we have argued for a paradigm shift that will begin to weaken the stranglehold of the standard English model in ELT in Japan. We suggested some pedagogical implications involving nonstandard Englishes in Japanese EFL classrooms, which included giving increased value to NNSNNS interactions in EFL teaching. By enhancing familiarity with different 
varieties of spoken English, learners will be empowered to acquire language skills and worldviews that contribute to enriching international communications. Most importantly, by legitimizing Englishes other than the American/British varieties that Japanese people are so used to, learners would be able to begin to challenge the monolithic Western-centric worldviews that are transmitted through conventional ELT theories and practices.

Kazufumi Miyagi currently teaches at the University of the Ryukyus and Okinawa Christian University. His interests include English varieties, multicultural awareness in L2 education, and EFL teacher training.

Masatoshi Sato is a PhD student at McGill University. His research interests include second language acquisition, interaction, and the proceduralization of grammatical knowledge, especially with EFL learners.

Alison Crump is a PhD student at McGill University. Her research interests include critical applied linguistics, language ideologies, and ESL/ EFL teacher training.

\section{References}

Bardovi-Harlig, K., \& Dörnyei, Z. (1998). Do language learners recognize pragmatics violations? Pragmatic versus grammatical awareness in instructed L2 learning. TESOL Quarterly, 32, 233-259.

Bhatt, R. (2001). World Englishes. Annual Review of Anthropology, 30, 527-550.

Bruthiaux, P. (2002). Hold your courses: Language education, language choice, and economic development. TESOL Quarterly, 36, 275-296.

Canagarajah, S. (1999). Resisting linguistic imperialism in English teaching. Oxford: Oxford University Press.

Canagarajah, S. (2006). An interview with Suresh Canagarajah. In R. Rubdy, \& M. Saraceni (Eds.), English in the world (pp. 200-212). London: Continuum International Publishing Group Ltd.

Cargile, A. (1997). Attitudes toward Chinese-accented speech: An investigation in two contexts. Journal of Language and Social Psychology, 16, 434-443.

Cortazzi, M., \& Jin, L. (1999). Cultural mirrors: Materials and methods in the EFL classroom. In E. Hinkel (Ed.), Culture in second language teaching and learning (pp. 196-219). Cambridge: Cambridge University Press.

Council of Local Authorities for International Relations [CLAIR]. (2002). JET Programme: Looking towards the future after 15 years [Brochure]. Tokyo: CLAIR. 
Council of Local Authorities for International Relations [CLAIR]. (2007). 2006-2007 JET Programme Participant Numbers. Retrieved May 15, 2007, from <http:// www.jetprogramme.org/e/introduction/stats.html>

Crump, A. (2007). Examining the role of assistant language teachers on the JET programme within the context of Nihonjinron and Kokusaika: Perspectives from ALTs. Unpublished master's thesis, McGill University, Montreal, Quebec, Canada.

Crystal, D. (2003). English as a global language (2nd ed.). Cambridge: Cambridge University Press.

Davies, A. (1991). The native speaker in applied linguistics. Edinburgh: Edinburgh University Press.

Foster, P., \& Ohta, A. S. (2005). Negotiation for meaning and peer assistance in second language classrooms. Applied Linguistics, 26, 402-430.

Graddol, D. (1997). The future of English? London: British Council.

Honna, N., \& Takeshita, Y. (1998). On Japan's propensity for native speaker English: A change in sight. Asian Englishes, 1(1). Retrieved March 2, 2005, from <http:// www.alc.co.jp/asian-e/honna.html>

Jenkins, J. (1998). Which pronunciation norms and models for English as an international language? ELT Journal, 52, 119-126.

Kachru, B. (1992). Teaching world Englishes. In B. B. Kachru (Ed.), The other tongue: English across cultures (2nd ed.) (pp. 355-365). Urbana, IL: University of Illinois Press.

Koike, I., \& Tanaka, H. (1995). English in foreign language education policy in Japan: Toward the twenty-first century. World Englishes, 14, 13-25.

Kowal, M., \& Swain, M. (1997). From semantic to syntactic processing: How can we promote metalinguistic awareness in the French immersion classroom? In R. Johnson \& M. Swain (Eds.), Immersion education: International perspectives (pp. 284-309). Cambridge: Cambridge University Press.

Kramsh, C., \& Sullivan, P. (1996). Appropriate pedagogy. ELT Journal, 50, 199-212.

Kubota, R. (1998). Ideologies of English in Japan. World Englishes, 17, 295-306.

Lippi-Green, R. (1997). English with an accent: Language, ideology and discrimination in the United States. New York: Routledge.

Matsuda, A. (2003). The ownership of English in Japanese secondary schools. World Englishes, 22, 483-496.

Matsuura, H., Fujieda, M., \& Mahoney, S. (2004). The officialization of English and ELT in Japan: 2000. World Englishes, 23, 471-487.

McArthur, T. (2003). English as an Asian language. English Today, 19, 19-22. 
McKay, S. (2002). Teaching English as an international language: Rethinking goals and approaches. Oxford: Oxford University Press.

Ministry of Education, Culture, Sports, Science and Technology [MEXT]. (2002). Kunibetsu sanka nin-zu 2002-2003 [Participants by countries of origin, 2002-2003]. Retrieved January 15, 2005, from <http://www.mext.go.jp/b_menu/shingi/ chousa/shotou/020/sesaku/020701d.htm>

Ministry of Education, Culture, Sports, Science and Technology [MEXT]. (2003). The course of study for foreign languages. Retrieved March 24, 2006, from http:// www.mext.go.jp/english/shotou/030301.htm

Miyagi, K. (2006). Japanese EFL teachers' perceptions of nonnative varieties of English: Are they ready to include other Englishes in their classrooms? Unpublished master's thesis, McGill University, Montreal, Quebec, Canada.

Morrison, R., \& White, M. (2005). Nurturing global listeners: Increasing familiarity and appreciation for world Englishes. World Englishes, 24, 361-370.

Musumeci, D. (1996). Teacher-learner negotiation in content-based instruction: Communication at cross-purposes? Applied Linguistics, 17, 286-325.

Niño-Murcia, M. (2003). "English is like the dollar": Hard currency ideology and the status of English in Peru. World Englishes, 22, 121-142.

Pennycook, A. (1994). The cultural politics of English as an international language. London: Longman.

Pennycook, A. (1998). English and the discourses of colonialism. London: Routledge.

Phillipson, R. (1992). Linguistic imperialism. London: Oxford University Press.

Pica, T. (2002). Subject-matter content: How does it assist the interactional and linguistic needs of classroom language learners? Modern Language Journal, 86, 1-19.

Pica, T., Lincoln-Porter, F., Paninos, D., \& Linnell, J. (1996). Language learners' interaction: How does it address the input, output, and feedback needs of L2 learners? TESOL Quarterly, 30, 59-84.

Rubdy, R., \& Saraceni, M. (Eds.) (2006). English in the world. London: Continuum International Publishing Group Ltd.

Sato, M. (2007). Social relationship in conversational interaction: Comparison of learner-learner and learner-NS dyads. JALT Journal, 29, 183-208.

Sato, M., \& Lyster, R. (2007). Modified output of Japanese EFL learners: Variable effects of interlocutor vs. feedback types. In A. Mackey (Ed.), Conversational interaction in second language acquisition: A series of empirical studies (pp. 123-143). Oxford: Oxford University Press. 
Smith, L. E. (1992). Spread of English and issues of intelligibility. In B. B. Kachru (Ed.), The other tongue: English across cultures (2nd ed.) (pp. 75-90). Urbana, IL: University of Illinois Press.

Storch, N. (2002). Patterns of interaction in ESL pair work. Language Learning, 52, 119-158.

Suzuki, T. (1999). Nihonjin wa naze eigo ga dekinai ka [Reasons why Japanese are poor at English]. Tokyo: Iwanami Shoten.

Swain, M., \& Lapkin, S. (1998). Interaction and second language learning: Two adolescent French immersion students working together. Modern Language Journal, 82, 320-337.

Tanaka, S. (1995). The Japanese media and English. World Englishes, 14(1), 37-53.

Tanaka, S. O., Tanaka, H. (1995). A survey of Japanese sources on the use of English in Japan. World Englishes, 14(1), 117-135.

TOEIC (2007). TOEIC tesuto katsuyo hokoku 2007 nendo-ban [Report on the Utilization of TOEIC 2007 Edition]. Retrieved October 9, 2008, from http://www.toeic.or.jp/ toeic/pdf/data/katsuyo_2007.pdf

Torikai, K. (2002). TOEFL•TOEIC to nihon-jin no eigo-ryoku [TOEFL•TOEIC and English proficiency of Japanese]. Tokyo: Kodansha.

Tsuda, Y. (1990). Eigo shihai no kozo [Structure of English domination]. Tokyo: Daisan Shokan.

Tsuda, Y. (1997). Hegemony of English vs. ecology of language: Building equality in international communication. In L. E. Smith, \& M. L. Forman (Eds.), World Englishes 2000 (pp. 21-31). Honolulu, HI: University of Hawaii Press.

Tsuda, Y. (2000). Eigo beta no susume [Recommendation to be poor at English]. Tokyo: KK Bestsellers.

Widdowson, H. G. (1994). The ownership of English. TESOL Quarterly, 28, 377-388.

Yoshikawa, H. (2005). Recognition of world Englishes: Changes in Chukyo University students' attitudes. World Englishes, 24, 351-360. 